\title{
THE FAST STUFF
}

\section{Making a connection.}

\section{BY GEORGE ZEBROWSKI}

$\int$ ulian loved the sudden tug of acceleration as the ship slipped into the steady single $g$ that ate up space, escaping the costly down payments of short boost's beggarly months of powerless drift to a planetary destination. But even this steady push brought the stars no closer.

A catastrophe waited for the Universe at light speed for ships made of the periodic table's answer to the questionings of the ancients; what is the world made of - so much better than the mythical charm of Earth, Air, Fire and Water.

It was, of course, only a logical catastrophe. A ship's increasing mass as it reached for light speed would need infinite energy to keep moving, and would suck all the energy of a universe if it made light speed; but he liked to imagine pressing his foot down on the accelerator at $99.99 c$ and risking cosmic disaster. Infinite mass was an absurdity, but one day a pilot would take a ship from point A to $\mathrm{D}$ and not know how he did it. Great Laumer had braved it, and no one knew what happened to him when he met the demon lurking at light speed.

Julian's coming to Lunar Farside, from which steady boost ships crossed the Solar System in weeks, had led him to dream of confronting the demon, logic be damned.

The nearer stars, invisibly closer now, were still decades away relative to Earth clocks, 20 to 100 years' round trip by ship time. But was anyone brave enough to provoke Einstein's mass-energy prohibition, or just content to cower at subluminal velocities? It seemed a pity if anyone hesitated in those last moments before light speed, just because Albert had given the problem "a little think".

Maybe the Universe would indulge a brave pilot.

Be happy with the fast ships we have.

The stars were brightest here at Lunar Farside, as Julian sat in the latest boost ship for a supply run to the Titan colony, trying not to think of the desert-streaked Earth

$\rightarrow$ NATURE.COM Follow Futures:

\section{y @NatureFutures}

$f$ go.nature.com/mtoodm hidden by the Moon, which he would see in a few moments. A home that had never afforded Lunar
Farside's base, or the colonies on Mars and Titan, priceless insurance prayers against human extinction, as his world struggled to rebuild.

Prisoners in our solar space, we can only

a delusion, waiting to awaken to this greater unreality.

"Julian here," he said into a silence. How could anyone answer him across light years? How far had he come; how long?

Suddenly he dropped down to the planetary system on his screen, in snapshots collapsing the distance.

Something didn't want to waste his time.

A blue world drowned the sky, and he swung around it. Lights flickered on the globe. Then in a series of sudden moments he was again hurled outward into the void.

"So now we know about each other," Julian said.

"You only saw a lot of lights, wherever you've been."

"I have a strong feeling I circled one of the planets at Centauri."

Farside's debriefing failed to make him doubt. His colleagues of many years seemed hostile strangers.

"I think we've been let out," he said.

"Let out? What do you mean?"

"My getting there means they

go in slow ships with no sure destinations.

Dreams are all we really have, he told himself, as the ship ramped up into the Lunar sky. He sat back and wished uselessly for a brave foot on an accelerator well beyond his ship's design. Male nonsense, he told himself, but the pressure at his back was always a godly thing, as joyous as when he had first known its wilfulness in small aircraft over the Chicago Wastes.

"Report," said a voice in his head.

"Routine," he said against all the starry glory around him. Immanuel Kant had respected only the starry heavens and the moral law within us, but the dark light years were a taunt; moral law a failure. The addicted escapees into virtual paradises on an Earth of tumbling deserts, where all wishes could be had, avoided reemerging into reality only with the lie of irreversible amnesia.

"Forgive me, Albert," he whispered, and a bright space opened up ahead, as if someone had mercifully lit a cave. A triple-star system waited. Three stars instructed him with familiar colours and brightness.

But he was here without additional acceleration. His life as a Farside pilot had been have been here. They've seen the ruin we've made of Earth, and opened a door for us."

"A door?"

"It had to be, because I did not exceed light speed ..." he said. "Jumps without acceleration. They opened it and I ran through."

His colleagues stared, unaccepting of the proof in the ship's pictures. "They must think us fools," one said bitterly, "to need their help. If we need it, we're not a breakout species."

"There and back," Julian said, "I broke no speed limits," then added with a sudden hope: "They want us out there." -

George Zebrowski's Brute Orbits won the John W. Campbell Memorial Award. Macrolife is listed in Library Journal's 100 Best SF Novels, and Stranger Suns was a New York Times Notable Book of the Year, both recently reissued. Cave of Stars is among Broderick and DiFilippo's Science Fiction: The 101 Best SF novels 1985-2010. His award-nominated stories have been collected in several volumes and all his works are at Open Road Media. Talks With The Masters: Conversations with Isaac Asimov, Ray Bradbury, Arthur C. Clarke and James Gunn is published by Wildside Press. 